\title{
Natural history of ventricular septal defect
}

\author{
Maurice Campbell \\ From the Cardiac Department, Guy's Hospital, and The Institute of Cardiology, London
}

Ventricular septal defect is the only cardiac malformation except persistent ductus where a normal life expectation may be restored by the defect closing spontaneously. Since 1960 this has been increasingly recognized in children but it is common also later, up to the fifth decade. About 20 per cent are living with a closed defect by 30, and 24 per cent by 60 years, both figures being $a$ little better than those for persistent ductus.

Closures occur mainly, but not exclusively, with small defects and normal pulmonary arterial pressures. This group, which forms nearly one-third of the total, has now an almost normal life expectation since treatment should eliminate the risk of dying from bacterial endocarditis.

The expectation of life for those with larger defects has been calculated from 25 deaths among II7 patients followed for 758 patient years. The mortality rate is high in the first two decades (2.2 and $2.9 \%$ per annum) and double the latter rate in the fourth and later decades.

Of those with larger defects, the calculated deaths are nearly 40 per cent during the first two decades and nearly 80 per cent at the end of the fourth decade. They are the only findings that can be compared with the age at death of reported necropsies. The latter are about 10 per cent worse at the end of each of the first four decades and have a mean age at death of 23 years compared with the calculated 27 years. Both these findings are worse than for the other cardiac malformations that have been discussed.

For all degrees of ventricular septal defect combined, the findings are of course better. Thus 27 per cent have died by 20 years and 17 per cent are living with a closed defect. By 40 years these percentages are 53 and 25, and by 60 years 69 and 25, the last figure being unchanged because normal mortality now balances the number closing. The mean age of all deaths, including those where the defect has closed, is 40 years. Only persistent ductus has a better outlook, though those with atrial septal defect fare better for the first three decades, and much better for two.

Again, the evidence about the incidence of bacterial endocarditis is conflicting. I can say only that the incidence is $0.9 \pm 0.4$ per cent per annum.

During the past 4 years I have written about the natural history of persistent ductus, congenital aortic and pulmonary stenosis, coarctation of the aorta, and atrial septal defect (Campbell, 1968a, b, 1969, 1970a, b). My patients with ventricular septal defect had been followed less completely because they were not then being operated on at Guy's. I have, however, worked out the times the 75 patients of Brotmacher and Campbell (1958a, b) were under observation and calculated their mortality rates. I have also been able to do this for series reported by Sandøe (1963) and Bloomfield (1964) and have been greatly helped by their valuable papers.

The widespread acceptance of the view of Roger (1879) that all lone ventricular septal

Received 24 August 1970. defects produced striking physical signs but no symptoms was a curious medical error. It was based on a few patients he had seen in life and his memory of a necropsy 18 years before on a boy. It was 12 years before there was necropsy proof of such a case that had been diagnosed in life by Dupré (1891), who suggested the unfortunate name maladie de Roger which took such a firm hold.

Roger had a lucky inspiration as regards defects of small size, but it is hard to understand what diagnosis was made of the larger defects that are more common. Most physicians accepted his view and taught it to their students. Even Brown (1939) in his great book devoted his whole chapter on ventricular septal defects to the maladie de Roger and congenital heart block. Cyanosis was hardly mentioned and he wrote, 'There are no symp- 
toms that can be attributed to this malady. Its characteristic feature is an absence of symptoms and marked physical signs' and, 'Normally it is quite compatible with a vigorous and active life'. Yet a few lines later he adds, 'The average age of death in Abbott's series was I4 years'.

Modern views began only with cardiac catheterization soon after the war, and the papers of Selzer (1949) and Wood (1950). Several workers, especially Cournand in New York, Dexter at Boston, and Bing at Baltimore showed that many patients with moderate or severe symptoms had large shunts through ventricular septal defects, often with important secondary effects on the pulmonary circulation.

Subjects with lesser degrees of obstruction or smaller openings obviously have a better outlook and generally less severe symptoms than those with greater degrees of the malformation. This is particularly true of ventricular septal defects with the wide range from small defects to those large enough to cause congestive heart failure in infants or pulmonary vascular disease (Eisenmenger's syndrome) in young people.

With obstructive malformations, children may become worse long before the heart begins to fail, because the stenosis becomes more severe owing to wear and tear caused by the circulation through it, and owing to its growing less than the normal parts of the body. I know no evidence to enable one to say that a gradient below a certain level will never increase and become important.

With ventricular septal defect, on the other hand, there is growing evidence that the size of the defect often becomes relatively or actually smaller as the child grows. The fact that so few patients with ventricular septal - defects are seen after 40 and even fewer after 50 years of age was always difficult to understand. It could be because those with larger defects have died as a result of them, and those with smaller defects feel too well to consult a doctor. This can hardly be the whole explanation because so few elderly patients with small - defects are seen with other illnesses. I can remember at least two elderly men in whom a ventricular septal defect followed cardiac infarction, but only one in whom it was congenital: he was in his 60's and I knew it was congenital only because he had married a doctor who knew his systolic murmur and thrill had not changed since his early 20's when she first listened to it and was told that a diagnosis of ventricular septal defect had been made when he was a boy.

Dammann and Carpenter (1968) in dis- cussing the treatment emphasize the importance of dividing patients into those with large, medium-sized, or small defects because of their very different effects and their influence on the natural history. In this study concerned with groups rather than individuals it seems enough to know the relative proportions with smaller defects likely to close and larger defects likely to produce increasingly serious effects.

This division will, therefore, be considered first, then the evidence from patients who have been recatheterized after an interval, and then the evidence about the number of defects that close spontaneously. The smaller defects rarely require surgical treatment (British Medical fournal, 1967, on Holmes Sellors's (1967) masterly lecture on heart surgery).

\section{Proportion with smaller defects}

There are nearly as many classifications as authors, but most of them use five groups, starting with two groups with normal or near normal pulmonary arterial pressures, (a) with smaller and (b) with larger left-to-right shunts. Then there are often two intermediate groups with larger shunts, (a) with pulmonary arterial pressures moderately raised and (b) with those nearer systemic level. Finally there is the group with fully developed Eisenmenger's complex.

The number in the first group with smaller defects and a normal pulmonary arterial pressure from seven series is shown in Table $I$. The percentages vary from 15 to $4 \mathrm{I}$ per cent. When three of the first four series calculated chanced to show such close agreement as

TABLE I Percentage of subjects with ventricular septal defects and with normal pulmonary arterial pressure and pulmonary flow generally less than twice systemic flow

\begin{tabular}{|c|c|c|c|}
\hline \multirow[t]{2}{*}{ Authors } & \multirow{2}{*}{$\begin{array}{l}\text { Total No. } \\
\text { of patients } \\
\text { with VSD }\end{array}$} & \multicolumn{2}{|c|}{$\begin{array}{l}\text { With smaller } \\
\text { defects }\end{array}$} \\
\hline & & No. & $\%$ \\
\hline \multicolumn{4}{|l|}{ Brotmacher and Campbell } \\
\hline & I 57 & 34 & 22 \\
\hline $\begin{array}{l}\text { Wood, Magiason, and } \\
\text { Wilson (r954) }\end{array}$ & 60 & 22 & $36 \cdot 5$ \\
\hline Mannheimer et al. (1957) & 72 & 27 & $37 \cdot 5$ \\
\hline Sandøe (1963) & 87 & 31 & $35 \cdot 6$ \\
\hline Bloomfield (I964) & 424 & 175 & 41 \\
\hline Schrire et al. (1965) & 160 & 63 & 39 \\
\hline Ritter et al. (1965) & 273 & $4 I$ & 15 \\
\hline Total & 1233 & 393 & 32 \\
\hline
\end{tabular}


$36.5 \pm$ I per cent, I thought the true figure unlikely to be less than 30 per cent.

Brotmacher and Campbell (1958a) found only II of their 57 patients with a normal pulmonary pressure and one is excluded on an extremely large pulmonary flow. But the more disabled patients had been chosen for catheterization. In 100 others who had not been catheterized, 24 were almost certainly in the group with small defects, making 34 of $157(22 \%)$. Sandøe (1963) put 43 patients in his group, but allowed pulmonary arterial pressures up to $35 \mathrm{~mm}$. Hg. Omitting those where it was above $30 \mathrm{~mm}$. reduced the number to 31 of the 87 patients.

Bloomfield (1964) thought that all his patients in his first two groups (64\%) would do well, but here I have included only those in his first group. The series of Ritter et al. (1965) was perhaps overweighted with more severe cases.

In these seven series combined, 393 of 1233 patients $(32 \%)$ had small defects with normal pulmonary arterial pressures. Most of them (probably over $80 \%$ ) were in the first two decades, so should give a reasonable estimate for our subsequent calculations.

\section{Patients who have been recatheterized}

If enough patients had been recatheterized after the lapse of many years, we should get a clear picture of the natural history of ventricular septal defect. At present most recatheterizations were after an interval of only 4 to 8 years and their mean age was still under 13 years. Even so, they give some useful information.

The results from 89 patients, excluding those where the defect was found to have closed, have been analysed and are summarized in Table 2. They are from the following seven series - Gasul et al. (I957), Brotmacher and Campbell (1958a), Lynfield et al. (196r), Howitt and Wade (1962), Sandøe (1963), Bloomfield (1964), and Ritter et al. (1965). Unfortunately the interval was generally only short and most of them were followed from the first to the second decade.

Normal pulmonary arterial pressure 24 patients had a normal pulmonary arterial systolic pressure (PASP) of $30 \mathrm{~mm}$. or less. None showed any progressive changes. Most of these patients (18) were followed from the first to the second decade (mean ages 7 to 13 years). Five others were followed from the second to the third decade (mean ages 15 to 23 years); and one patient from 4I to 49 years.
TABLE 2 Results of recatheterization after mean interval of 6 years (above) and mean age of subjects (below)

\begin{tabular}{|c|c|c|c|c|}
\hline $\begin{array}{l}\text { Pulmonary arterial } \\
\text { systolic pressure }\end{array}$ & $\begin{array}{l}\text { No. of } \\
\text { patients }\end{array}$ & Improved & No change & Worse \\
\hline Normal & 24 & - & 24 & - \\
\hline Moderately increased & 22 & $12^{\star}$ & 9 & $\mathbf{I}$ \\
\hline Approaching systemic levels & 43 & $4^{\star}$ & 20 & 19 \\
\hline Total number & 89 & 16 & 53 & 20 \\
\hline
\end{tabular}

\begin{tabular}{llll}
\hline Mean age $(y r)$. & No. of patients & Mean age $(y r)$. & No. of patients \\
\hline $6-11$ & 77 & $25-32$ & 3 \\
$15-23$ & 6 & $39-47$ & 3 \\
\hline
\end{tabular}

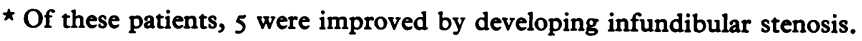

Moderate increase Twenty-two patients had a PASP between 33 and $69 \mathrm{~mm}$. Most (20) were followed from the first to later in this decade or to the second decade (mean ages 4 to 9 years), one from 15 to 22 years, and one from 21 to 31 years. Only this last patient changed significantly for the worse, his PASP rising from 46 to $60 \mathrm{~mm}$. and his $\mathrm{O}_{2}$ saturation falling to 92 per cent. Nine showed no significant change. More than half (12) were improved, their PASP of about 40 falling to normal or those of about 60 falling to about $40 \mathrm{~mm}$. Two of these owed their improvement to the development of pulmonary infundibular stenosis. Their PASPs of $5 \mathrm{I}$ and $56 \mathrm{~mm}$. had fallen to normal with gradients of 24 and $36 \mathrm{~mm}$.

The evidence in this group is confined almost entirely to those in the first decade.

Pulmonary pressures approaching systemic levels Forty-three patients had a PASP of $70 \mathrm{~mm}$. or more, which was over $80 \mathrm{~mm}$. in all but Io and often at or near systemic levels. Again, most of these (39) were catheterized in the first and second decades (mean ages 6 to 12 years). Two were catheterized in the 3rd and 4th and 2 in the 4 th and 5th decades (mean ages 27 to 33 years, and 38 to 46 years).

About equal numbers showed little change (20) or distinct deterioration (19). Most of them were followed only about 6 years from the middle of the first decade. Even so, nearly half showed rising pulmonary arterial pressures often up to systemic level. The arterial $\mathrm{O}_{2}$ saturation was often much lower, e.g. 94 to 69 and 90 to 67 , though many falls were much less than this. However, only 2 of the I6 losing ground kept an $\mathrm{O}_{2}$ saturation of over 92 per cent. One patient showed a fall of PASP from 8I to $56 \mathrm{~mm}$. Three others showed falls that were due to the development of pulmonary infundibular stenosis, one from 89 
to $64 \mathrm{~mm}$. and two from about 72 to a normal level, the gradients being from 25 to $5 \mathrm{I} \mathrm{mm}$. These changes were in the first decade. The patients seemed better but how long the advantage would last must be uncertain.

Summary When the PASP is normal, it remains so till the 20's. There is not much evidence after this, but what there is suggests that patients continue well.

When the PASP is about 40 to $65 \mathrm{~mm}$. patients are almost equally likely to remain the same or improve, but most of the evidence is limited to the first decade. Observations at later ages are badly needed.

When the PASP is approaching systemic levels, about equal numbers remain the same or deteriorate during the time (mean of 6 years) they are under observation. A few improve for a time by developing pulmonary infundibular stenosis.

\section{Spontaneous closure of ventricular sep- tal defects}

That a persistent ductus may close spontaneously after infancy has been recognized for a long time. Brown (I950) mentioned some personal and reported examples, and wrote, 'the adult case of patent ductus is a rare visitor to the clinic, and the condition appears to be equally rare in routine post-mortem examinations. It therefore seems that there must be spontaneous closure more often than is generally realized or cases are missed when failure supervenes and the characteristic physical signs disappear'.

Campbell (I968a) brought forward evidence that the rate of closure was 0.6 per cent per annum during the first four decades, though probably rather less later. This would mean that it closed spontaneously in I5 per cent of all patients by the age of 30 and in 20 per cent by 60 years.

Brown's remarks about persistent ductus would have been equally applicable to small ventricular septal defects where spontaneous closure was regarded as rare. Only occasional examples were reported. French (1918) de'scribed one in a boy where the diagnosis was made at 14 months and confirmed a year later, yet at 5 years and at ro years the systolic murmur and thrill had disappeared. His article led to two more patients being reported in letters to the Guy's Hospital Gazette (1918, 32, I46), and Parkes Weber (I9I8) reported another example. There were not many.

Recent reports show that it happens much more frequently. Evans, Rowe, and Keith (I960) found that loud systolic murmurs, generally with a thrill and suggestive of ven- tricular septal defect, had disappeared in 35 infants, in 5 of whom it was proved that the defect had closed. Of the closures, 80 per cent were before the age of 3 years. Agustsson et al. (196I) reported closure, complete or partial, in 8 of 195 catheterized patients, in half of whom the defects had been large enough to cause pulmonary plethora and large hearts.

Nadas et al. (196I) proved by recatheterization that the defect had closed in 4 children, 3 of whom had pulmonary arterial pressures between 50 and $90 \mathrm{~mm}$., and in all 3 it returned to normal afterwards. Wade and Wright (1963) reported another 5 examples, the eldest child being 13 years old when it closed.

Hoffman and Rudolph (1965) followed 62 infants with ventricular septal defects, all catheterized when under I year, and 40 of them recatheterized from I to 5 years later. They were not trivial cases, for half of them had congestive heart failure during their first year. In spite of this the ventricular septal defect had closed in $15(24 \%)$. In another 17 the defect had become smaller.

Campbell (1968c) brought forward indirect evidence that the closure of ventricular septal defects is of frequent occurrence, probably 30 per cent of all cases. He found a different distribution of various malformations of the heart at birth, in schoolchildren, and at clinics for children and adults. In several malformations, the exceptionally heavy mortality in the first year of life accounted for most, if not all, of the difference. With ventricular septal defect, however, it accounted only for part of the difference, leaving about 30 per cent unexplained.

Ventricular septal defect is far the commonest malformation at birth, 28 per cent of the total. Among schoolchildren it still forms nearly a quarter $(24 \%)$, but in clinics for children and adults it falls to 17 per cent, the same as atrial septal defect and only a little more than persistent ductus.

Carlgren (1959) was one of the three groups of authors who had provided the main data for the incidence of different malformations at birth and their heavy mortality in the first year of life. He wrote that a majority of ventricular septal defects were clinically insignificant. He has continued his investigation for another ro years and, in general, finds the same incidence of the different malformations with only slight reduction in the early mortality (Carlgren, 1969).

In this second paper, Carlgren expressed more decisive views about children with highpitched low-intensity murmurs round the fourth intercostal space - murmurs that tend 
to disappear. He thought they had small ventricular septal defects and that the defect had closed within a few years when the murmur disappeared. This decision increased their incidence considerably from 31 to $\mathbf{4 2}$ per cent of all infants with cardiac malformations in $195 \mathrm{I}-60$, subsequently followed and often fully investigated.

Of the 190 infants with ventricular septal defects, 83 had small defects that had closed; and 6I (58) had small defects and 46 (50) had larger defects that were still open, the figures in brackets showing the average for the two Io-year periods $194 \mathrm{I}-50$ and $195 \mathrm{I}-60$. This means that 58 per cent of small, and over 43 per cent of all, ventricular septal defects have closed within a few years. Carlgren emphasizes that this depends on his clinical diagnosis, but with the findings of Hoffman and Rudolph (1965) just quoted it should be accepted.

I am greatly indebted to Carlgren for writing to me about the ages at which these defects were found to have closed. Twenty-six closed in the subject's first year. Eighteen were found closed during their second year but only one of these was known to have closed that year. Thirty-six were found to be closed between their 3rd and 9th years; 5 were known to have closed during this period, but 17 might have closed in their second year and I4 possibly even before this.

Between their roth and 19th years, 3 more were found to have closed, but 2 of these might have closed somewhat earlier. Thus Carlgren has found a very high rate of closure, especially in the first 3 years.

Hollman (1967) accepts that many small and some larger defects close spontaneously mainly in the first 5 years. Closure is not, however, confined to childhood. Bloomfield (1964) in a most valuable paper gives details of a woman whose signs disappeared when she was 26: when she died with pneumonia 7 years later, necropsy showed a closed scarred depression at the usual site of a ventricular septal defect.

Bloomfield tried to trace 48 patients of Evan Bedford and myself, who had been diagnosed, on what still seemed reasonably good evidence, as ventricular septal defects at the National Heart Hospital, London, in 1934-39. Of these patients, 29 were traced to their death or for re-examination from 21 to 26 (average 24) years later. In 5 of the 29 the diagnosis had been wrong: pulmonary stenosis in 2, and ostium primum in $\mathrm{I}$, aortic stenosis in $I$, and mitral regurgitation in $I$. In the 24 others there was no reason to think it had been incorrect.
Of these 24,3 had died, I, 4 , and I I years after they had been seen; 7 still had signs of a ventricular septal defect; but $14(57 \%)$ had lost their murmur and thrill and the defect was assumed to have closed. The patients in both the living groups felt quite well and had often forgotten that their hearts had been said to be affected. Few of them were willing to come to hospital again, though they gladly co-operated when Bloomfield went to see and examine them at home or at work. Of the 7 patients (average age 40.6 years) located who still had a defect, only I attended her doctor and only 3 knew that they had a murmur. It is, therefore, easy to understand how these patients are often lost to follow-up. Bloomfield had employed the Salvation Army's Investigation Department to trace many of them as well as the more usual Register of Deaths. The Register showed that none of the 19 untraced patients had died in the United Kingdom, so probably their defects had closed in the same proportions as in the other 24.

Bloomfield (1964) divided the patients into I4 of his group I, 8 of group 2, and 2 of group 3. Both patients in group 3 had died and the third death in group 2 was from bacterial endocarditis. No other patient in groups I or 2 had lost ground and many had improved.

In 14 of the 24 patients the defect had closed (Table 3). We do not know exactly when - between the ages of 4 and 35 in 8, between the ages of II and 46 in 5, and after this age in $r$. There is no reason to think that large numbers closed in their 5th or 12th years soon after visiting hospital.

The last man was discharged from the army with a systolic murmur and a large heart; he

TABLE 324 patients diagnosed as VSD by Bedford and Campbell in 1934-39 followed till death or for 21-26 years (Bloomfield, I964)

\begin{tabular}{|c|c|c|c|c|c|}
\hline $\begin{array}{l}\text { Age (1934-39) } \\
\text { (yr.) }\end{array}$ & $\begin{array}{l}\text { No. of } \\
\text { patients }\end{array}$ & Dead & $\begin{array}{l}\text { Still } \\
V S D\end{array}$ & $\begin{array}{l}V S D \\
\text { closed }\end{array}$ & $\begin{array}{l}\text { Closing rate } \\
\% \text { per annum }\end{array}$ \\
\hline \multicolumn{6}{|l|}{ Small defects } \\
\hline Up to Io & 8 & 0 & 2 & 6 & 一 \\
\hline II and over & 6 & 0 & 2 & 4 & 一 \\
\hline Total & 14 & 0 & 4 & IO & $3 \cdot 0-4 \cdot 2$ \\
\hline \multicolumn{6}{|c|}{ Larger, but not very large, defects } \\
\hline Up to Io & 4 & $\mathbf{I}$ & $\mathbf{I}$ & 2 & 一 \\
\hline I I and over & 6 & 2 & 2 & 2 & - \\
\hline Total & Io & 3 & 3 & 4 & $2 \cdot 3-3 \cdot 0$ \\
\hline Grand total & 24 & 3 & 7 & 14 & 一 \\
\hline
\end{tabular}


attended the Heart Hospital with a systolic murmur and thrill and a prominent pulmonary artery when he was 46 ; yet when 69 , he had less dyspnoea than in the past and his systolic murmur and thrill had disappeared. The defect, therefore, closed some time after 46 years of age. Table 3 shows that Io of the I4 $(7 \mathrm{I} \%)$ patients with smaller defects had closed about 24 years later, and 4 of the ro $(40 \%)$ in group 2 with more signs of pulmonary plethora. No cyanotic patients were in this follow-up and probably none with a very high pulmonary arterial pressure. I have calculated the rate of closing as percentages per annum, and this is shown in the last column of Table 3 on two alternative assumptions.

Assuming all closures had taken place in the latter half of the period, ro smaller defects had closed in 326 patient-years, a high rate of 3 per cent per annum. The 4 larger, but not very large, defects had closed in 174 patientyears, still a high rate of 2.3 per cent per annum. It seems more reasonable to assume that the times of closure were equally distributed throughout the 24 years of the followup. In this case the number of patient-years would be 239 and 136, respectively, and the closing rates would be 4.2 for the smaller and 3.0 per cent per annum for the somewhat larger defects. For my calculations about the smaller defects I have, therefore, used the rate of 4.2 per cent.

Mannheimer, Ikkos, and Jonsson (1957) did a similar retrospective study of 14 patients diagnosed as ventricular septal defect 20 to 25 years before at Norrtull's paediatric clinic. Two still had ventricular septal defects, 2 were errors of diagnosis having atrial septal defect and pulmonary stenosis, and the other Io had normal hearts. They assumed these were errors of diagnosis, but it seems much -more likely that their ventricular septal defects had closed. If so, Io closures in 315 patient-years would give a closure rate of 3.2 per cent per annum.

Bloomfield (1964) reported also 12 defects that had closed and 13 that were still open among 67,000 necropsies from four hospitals. ,Of these closed defects, ro were large and only 2 small, but none had produced pulmonary vascular disease.

Simmons, Moller, and Edwards (1966) found 7 examples of closed defects among 1605 necropsies. The ages at death of these 7 subjects were between 39 and 90 but, of course, the defects may have closed at any time.

\section{Some general considerations}

The remainder of this paper is concerned with calculating rates of closure and mortality for those who survive the hazards of the first year of life. A few papers that are important for the natural history but cannot be used for these calculations will be dealt with first.

The complicated changes in pulmonary blood flow and vascular resistance, normally and in those with septal defects or persistent ductus, have been ably discussed by Rudolph (1968, 1970). Normally, the pulmonary vascular resistance drops to near normal adult levels within two weeks, but with large ventricular septal defects it falls more slowly over 6 to 9 months, and the thick-walled muscular vessels of the foetal type persist for longer. There is a significant fall in pulmonary vascular resistance in nearly all infants born at sea-level with a ventricular septal defect for several months after birth; but about Io to 15 per cent of them show a subsequent rise from 9 to 18 months after birth.

The increased pulmonary arterial pressure seems a more important cause than the increased flow. Thus, with atrial septal defects the rise is uncommon before 20 years of age and the histological changes are different.

Ritter et al. (1965) found 78 of their 273 patients had congestive heart failure within their first two years. Of those treated medically 27 per cent died, but of those where an attempt was made to close the defect surgically 46 per cent died.

DuShane (I968) gives an excellent picture of its natural history in the early years from the surgical aspect. A pulmonary blood flow twice or more the systemic flow was, he thought, generally agreed reason for closing the defect; but there was no agreement about infants with intractable cardiac failure or older patients with a high pulmonary vascular resistance.

When vigorous medical treatment of the cardiac failure did not succeed, he thought the pulmonary artery should be banded, with a curative operation later - later, because in those under 7 years the operative mortality was 9 per cent, but after this it was only about 2 per cent.

Where the pulmonary vascular resistance was less than 0.45 of the systemic resistance, operation was generally successful; where it was more than this but less than 0.75 of the systemic, operation succeeded in about 70 per cent; but where it was more than 0.75 times the systemic, operation succeeded in under 30 per cent.

In a 5 to 16 years follow-up of 65 patients with pulmonary vascular obstructive disease who had no operation, only 7 were lost sight of. Only 2 of the 35 under 19 years had died, but 9 of the 23 over 19 had died. 
Blount and Woodwark (1960) reviewed 300 patients. They thought the first two years a critical period, after which most patients did well for about a decade and a half. Later there was an increasing tendency to a rising pulmonary vascular resistance. Only 8 of their 300 patients were over 40 years of age.

Brotmacher and Campbell (1958a, their Fig. 8) found a fairly close correlation between increasing pulmonary vascular resistance and age, when patients with normal pulmonary arterial pressures were excluded. They concluded that patients who had survived infancy had a fairly good outlook for 15 years or so but thereafter a much more uncertain one.

Wood (1958) pointed out the similarity of the haemodynamic situation with pulmonary hypertension whether the shunt was at ventricular, aorto-pulmonary, or atrial level. $\mathrm{He}$ proposed the name Eisenmenger syndrome and defined this as pulmonary hypertension due to a high pulmonary vascular resistance with a reversed or bidirectional shunt at any of these levels.

The Eisenmenger syndrome has the unenviable distinction of an excessively high maternal mortality rate in pregnancy. Morgan Jones and Howitt (1965) collected 1284 pregnancies, including 188 personal cases, in women with cardiac malformations. The maternal mortality was 27 per cent in 37 women with the Eisenmenger syndrome, but only $\mathrm{I} \cdot 8$ per cent in the 1247 women with all other cardiac malformations. It reached 4 per cent only in women with coarctation of the aorta or Fallot's tetralogy.

Sandøe (1963) correlated the age and pulmonary arterial pressure in 309 patients from his own series and those of Joly, Carlotti, and Sicot (195I), Blount, Mueller, and McCord (1955), Hubbard, Angle, and Koszewski (1957). and Garcia et al. (1960). The proportion with pressures over $70 \mathrm{~mm}$. increased from 32 in the first decade to 68 per cent in the third and later decades. Obviously some patients develop increased pressures with age, but he thought many older patients with normal pressures did not come to hospital and were not selected for investigation. He did not then accept the explanation that many of the smaller defects had closed. But I think this explains much of the difference and prevents one deducing in how many the pressure may have increased with age.

Patients with aortic regurgitation from prolapse of an aortic cusp through the defect are a special group. Blumenthal (1968), reporting 17 such patients, emphasizes the need for operation before the regurgitation has progressed too far. In another group with a right- sided aortic arch, Varghese et al. (1970) found a striking tendency to the development of infundibular stenosis, but this development may occur with a left-sided arch.

Clinically, there may often be long periods of stability, but there may be abrupt changes. Two examples, perhaps as striking as any, were reported by Selzer and Laqueur (I95I). One man who had been cyanotic from childhood was still living at 57 years. A woman worked as a tram-conductress, on her feet for 14 hours a day, until she became blue at the age of 36 : she died within 3 years. Among their 30 patients with Eisenmenger's complex, roughly equal proportions had become cyanotic from infancy, from childhood, and from adult life, but Wood (1958) thought 80 per cent had been cyanotic from infancy or childhood.

\section{Subsequent course and number closing of those with small ventricular septal defects}

There seems no evidence that patients with small defects and normal pulmonary arterial pressures deteriorate as the years pass. None of the 20 in this group showed unfavourable changes at their second catheterization, about seven years after the first (see p. 248). Brotmacher and Campbell (1958a), Sandøe (1963), and Bloomfield (1964) found no clinical deterioration in this group, and the latter found all his patients in group $I$ and half of those in his group 2 were unchanged or occasionally improved 8 to I2 years later. Most of these patients were in the first two decades but several were in the third, and one in the fifth.

Bloomfield (1964) related the ages and causes of death of I I 5 patients of all ages with the age-standardized size of the defect (his Fig. 6). He concluded that smaller ventricular septal defects, less than I I mm. in diameter, never led to the pulmonary hypertensive complications that cause many deaths.

These patients are, of course, unduly prone to bacterial endocarditis. In the past this caused many deaths, but should not do so now. With aortic stenosis and with bicuspid aortic valves, bacterial endocarditis still leads to some deaths by producing gross aortic regurgitation before the infection is brought under control, but there is no similar risk with septal defects.

It was hard to accept this good prognosis when so few patients with small defects were seen in later life. Now we know it is because so many of them close spontaneously. There is good evidence that this is the only important change likely to occur in the first three decades, and $I$ have assumed this continues in 
later decades, but here more evidence is desirable.

I have, therefore, calculated the numbers that have closed at the end of each decade, using a closing rate of 4.2 per cent per annum, and assuming their mortality is the same as that of normal subjects. Possibly this rate is too high for later decades but too low for the first decade. The latter would have a greater effect on increasing the numbers closed because of the larger numbers at risk then.

The first line of Table 4 shows that over half have closed by 20 years, 80 per cent by 40 years, and 90 per cent by 60 years. Calculations were made for each year but are shown only for the end of each decade. The second line shows the number still living with the defect closed and the third line the number still living with the defect open. The bottom line shows the normal mortality from Life Table No. I I of the Registrar General (I957), and this obviously affects the subjects equally whether their defect is open or closed.

Bacterial endocarditis was the only special risk for these patients and the figures in parentheses show what the findings would have been with all subjects who acquired this dying. Now that it can be cured, their mortality should be the same as for normal subjects. This is so low in the first four decades that the figures in the first two lines are almost the same till 40 years. Thereafter, as normal mortality increases, the number of deaths among those with a closed defect balances and finally overtakes the number of new closures.

The number still living with the defect open is only 12 per cent by 50 years and much less afterwards. Patients of this age are so rarely seen with signs of a defect that I believe the rate of closure used for my calculations may be too low. The figures in the last three lines of each column must of course add up to Ioo.

\section{Mortality rates and calculations of num- bers dying among patients with larger defects}

In previous papers I have worked out the - patient-years for all those with the malformation under consideration. Here I started in the same way but decided to calculate separately the outlook for patients with small defects and normal pulmonary arterial pressures (Table 4). These and their patient-years must, therefore, be excluded in calculating mortality rates for the majority $(68 \%)$ with larger ventricular septal defects that produce severe symptoms and a graver outlook.

There was so little information for the fifth and later decades that my mortality rates have been calculated for the first three decades separately and for the fourth and later decades together in Table 5. The calculated mortality rate is high for the first decade, $2 \cdot 2$ per cent per annum, and rises steadily to 2.9 , to 3.4 , and to 5.8 per cent per annum for the fourth and later decades.

These calculations are based on 25 deaths among II7 patients, 432 patient-years being from personal patients, 182 patient-years from Sandøe (1963), and I44 patient-years from Bloomfield (1964). It is not a large number considering the amount that has been written about ventricular septal defect in recent years, but follow-up studies with adequate data are less common than I would wish. The patient-years are, however, slightly more than those used for aortic coarctation (7I6) and atrial septal defect (663).

The calculated percentages still living and the percentages dead at the end of each decade are shown in the first two lines of Table 6, excluding deaths in the first year. The percentages of deaths of normal subjects are shown in the third line. In the first four decades the deaths of patients with large defects are about 20 times as many as normally. They are still Io times as many in the fifth decade. After this as the normal death rate rises the difference is not quite so much.

More than half the subjects have died by the age of 30, three-quarters by 40 , and nearly 90 per cent by the age of 50 years. Only I I per cent are living at 50 and I believe the numbers shown as living at 60 and 70 are too large, which means that some of my mortality rates are too low. The mean age at death is only 27 years. Those with the larger ventricular septal defects have a worse outlook than the whole range of those with other common cardiac malformations.

\section{Age at death in reported necropsies}

In recent papers I have been able to compare my calculated cumulative mortality with the mortality shown by reported necropsies and have been pleased with the relatively close agreement. Here, as with persistent ductus, the comparison is invalid because of the patients where the opening has closed spontaneously.

The ages at death of 136 patients with reported necropsies who survived their first year are shown in Table 7. Their mean age at death was 23 years. Obviously those where defects had closed were not included. Even so, 28 per cent had died in the first decade compared with the calculated 18 per cent of my Table 6. This difference is maintained for four decades, 
TABLE 4 Calculated expected closures and deaths as percentages among subjects with small (group I) ventricular septal defects

\begin{tabular}{|c|c|c|c|c|c|c|c|}
\hline Age & At ro & At 20 & At 30 & At 40 & At 50 & At 60 & At 70 \\
\hline Closures & 32 & $54(5 I)^{\star}$ & $70(63)$ & $80(70)$ & $86(75)$ & $90(77)$ & 93 (79) \\
\hline $\begin{array}{l}\text { Still living with closed VSD } \\
\text { Still living with open VSD } \\
\text { Deaths }\end{array}$ & $\begin{array}{l}32 \\
67(62)^{\star} \\
I(6)\end{array}$ & $\begin{array}{l}54(50)^{\star} \\
45(39) \\
\text { I (II) }\end{array}$ & $\begin{array}{r}68(62) \\
29(24) \\
3(14)\end{array}$ & $\begin{array}{r}77(68) \\
19(14) \\
4(18)\end{array}$ & $\begin{array}{l}80(69) \\
12(8) \\
8(23)\end{array}$ & $\begin{array}{l}76(64) \\
6(3) \\
18(33)\end{array}$ & $\begin{array}{l}58(45) \\
3(1) \\
39(54)\end{array}$ \\
\hline
\end{tabular}

* The smaller figures in parentheses indicate the earlier position when bacterial endocarditis was fatal and attacked about I per cent of these patients.

which again suggests that I have underestimated the early mortality and so show too many surviving to later decades.

\section{Calculated mortality of patients with all grades of ventricular septal defect com- bined}

The two-thirds with larger defects shown in Table 6 have been combined with those having small defects (Table 4) to give a picture of ventricular septal defect as a whole. The calculated number of deaths among 1000 subjects living at I year is shown in the second line of Table 8. Nearly 40 per cent have died by 30 years and 80 per cent by 70 years, the defect having closed spontaneously in most of those who are still living. The Fig. shows the percentages at each age of deaths on the left with the upper scale; and on the right with the lower scale, those living with the defect closed, and those living with it still open.

These show a better outlook than any other common cardiac malformation except persistent ductus arteriosus, these being the only two conditions where closures give some of the subjects a normal expectation of life. Actually the proportion where the defect closes is a little higher with ventricular septal defect than with persistent ductus, just over 20 against 15 per cent at 30 years, and 24
TABLE 5 Mortality rates by decades for all patients with larger VSDs*

\begin{tabular}{|c|c|c|c|c|}
\hline Decades & Patients & Patient-years & Deaths & $\begin{array}{l}\text { Mortality rates } \\
\% \text { per annum }\end{array}$ \\
\hline $\begin{array}{l}\text { First } \\
\text { Second } \\
\text { Third } \\
\text { Fourth } \\
\text { Fifth and later }\end{array}$ & $\begin{array}{l}52 \\
38+(17) \dagger \\
12+(13) \\
10+(8) \\
5+(4)\end{array}$ & $\begin{array}{r}229 \\
275 \\
116 \\
95 \\
43\end{array}$ & $\left.\begin{array}{l}5 \\
8 \\
4 \\
6 \\
2\end{array}\right\}$ & $\begin{array}{l}2 \cdot 2 \\
2.9 \\
3.4 \\
5.8\end{array}$ \\
\hline Total & $117+(42)$ & 758 & 25 & $3 \cdot 3$ \\
\hline
\end{tabular}

* Based on personal patients and those of Sandøe (1963) and Bloomfield (1964). + These figures in parentheses denote patients who continued under observation to another decade.

TABLE 6 Calculated expected survivors and deaths as percentages among subjects with larger VSDs surviving at I year

\begin{tabular}{|c|c|c|c|c|c|c|c|}
\hline Age & $\begin{array}{l}A t \\
\text { IO }\end{array}$ & $\begin{array}{l}A t \\
20\end{array}$ & $\begin{array}{l}A t \\
30\end{array}$ & $\begin{array}{l}A t \\
40\end{array}$ & $\begin{array}{l}A t \\
50\end{array}$ & $\begin{array}{l}A t \\
60\end{array}$ & $\begin{array}{l}A t \\
70\end{array}$ \\
\hline $\begin{array}{l}\% \text { still living } \\
\% \text { dead }\end{array}$ & $\begin{array}{l}82 \\
18\end{array}$ & $\begin{array}{l}6 \mathrm{I} \\
39\end{array}$ & $\begin{array}{l}4 \mathrm{I} \\
59\end{array}$ & $\begin{array}{l}23 \\
77\end{array}$ & $\begin{array}{l}\text { II } \\
89\end{array}$ & $\begin{array}{r}6 \\
94\end{array}$ & $\begin{array}{r}4 \\
96\end{array}$ \\
\hline $\left.\begin{array}{c}\text { Deaths among roo } \\
\text { normal subjects } \\
\text { surviving at I year }\end{array}\right\}$ & $\mathbf{I}$ & I & 3 & 4 & 8 & 18 & 39 \\
\hline
\end{tabular}

TABLE 7 Age at death in reported necropsies over one year

\begin{tabular}{|c|c|c|c|c|c|c|c|c|c|}
\hline Decades & Ist & 2nd & $3 r d$ & 4 th & 5 th & 6 th & 7 th & 8 th & $A l l$ \\
\hline Selzer (I949) & 26 & 16 & 7 & 9 & 2 & $\mathbf{I}$ & 2 & I & 64 \\
\hline Selzer and Laqueur (195I) & 6 & 6 & 7 & 7 & $\mathbf{I}$ & 3 & 0 & 0 & 30 \\
\hline \multicolumn{10}{|l|}{$\begin{array}{l}\text { Brotmacher and Campbell (1958a), } \\
\text { Sandøe (1963), and Bloomfield }\end{array}$} \\
\hline (1964) & 6 & 8 & 12 & 7 & 6 & 3 & 0 & 0 & 42 \\
\hline Total & 38 & 30 & 26 & 23 & 9 & 7 & 2 & I & 136 \\
\hline Percentages & 28 & 22 & 19 & 17 & $6 \cdot 5$ & 5 & I.7 & 0.8 & \\
\hline Cumulative percentage & 28 & 50 & 69 & 86 & $92 \cdot 5$ & $97 \cdot 5$ & $99 \cdot 2$ & 100 & \\
\hline \multirow{2}{*}{$\begin{array}{l}\text { My calculated percentages for larger } \\
\text { defects (Table 6) }\end{array}$} & & & & & & & & & \\
\hline & 18 & 39 & 59 & 77 & 89 & 94 & 96 & - & \\
\hline
\end{tabular}


TABLE 8 Calculated expected deaths and survivors from 1000 subjects with all types of VSD living at I year

\begin{tabular}{lrrrrrrr}
\hline & At I0 & At 20 & At 30 & At 40 & At 50 & At 60 & At 70 \\
\hline Deaths among I000 normal subjects & & & & & & & \\
$\quad$ living at I year & 8 & 14 & 26 & 44 & 83 & 179 & 392 \\
Deaths among IO00 subjects with VSD & 125 & 269 & 394 & 534 & 619 & 688 & 779 \\
Survivors with VSD closed & 102 & 172 & 219 & 245 & 256 & 243 & 185 \\
Survivors with VSD open & 773 & 559 & 387 & 221 & $125^{\star}$ & $69^{\star}$ & $36^{\star}$ \\
\hline
\end{tabular}

* I believe these figures are too large, which would mean that my mortality rates are too low.

against 20 per cent at 60 years. The evidence for the rate of closing is quite good for the first four decades but scanty after this.

The mean age at death for those dying with persistent ductus is 43 years compared with 3I for those dying with ventricular septal defect (Table 8), because the outlook for those with the former is so much better in the first four decades. If those where the defect closes and the subject has a normal life-expectation are included, the mean ages at death are raised to 48 and 40 years, respectively.

Atrial septal defect patients have a mean life expectation of $4 \mathrm{I}$ years though there is no real chance of their defects closing spontaneously. This relatively high figure is because their outlook is so good during the first two decades, nearly as good as for those with persistent ductus and much better than for those with other malformations. The mean expectation of life for those with congenital aortic stenosis is 35 years, for coarctation of the aorta 34 years, and for those with pulmonary stenosis just under 30 years. For larger ventricular septal defects, it is about 23-27 years, and the outlook for this subdivision is worse than for any other cardiac malformation so far considered.

\section{Incidence of bacterial endocarditis}

In older statistics, when every patient with bacterial endocarditis died, this was naturally a common cause of death in most cardiac malformations. Gelfman and Levine (1942) found it the cause of death in 16 per cent of all those - with some such malformation, and in 28 per cent of those with persistent ductus or pulmonary stenosis. It was as high as $\mathbf{5 7}$ per cent in those with small, and 4I per cent in all with ventricular septal defects. We can see now that the exceptionally high incidence was because in small defects there were few other conditions that killed these healthy patients. Even so, their figures are high compared with .the 19 per cent Selzer (1949) found among his reported necropsies, an incidence of about 0.9 per cent per annum.
More important is the recent attack rate in living patients. Shah et al. (1966) reported four clinical series where there were II instances of bacterial endocarditis in 3104 patient-years, a rate of 0.3 per cent per annum. My records of only one attack, from which the patient made a good recovery, may have failed to record some others since they give a very low rate of attack in 490 patient-years. Sandøe found 3 attacks in 292 patient-years. Combining these figures, there were 15 attacks in 3886 patient-years, a rate just under 0.4 per cent per annum. This is less than I

FI G. Percentages of subjects with ventricular septal defect at each year of age in three different states.

Those who have died are shown on the left, using the upper scale. Those who are living with the defect closed are shown in the middle. Those who are living with the defect still open are shown on the right, using the lower scale.

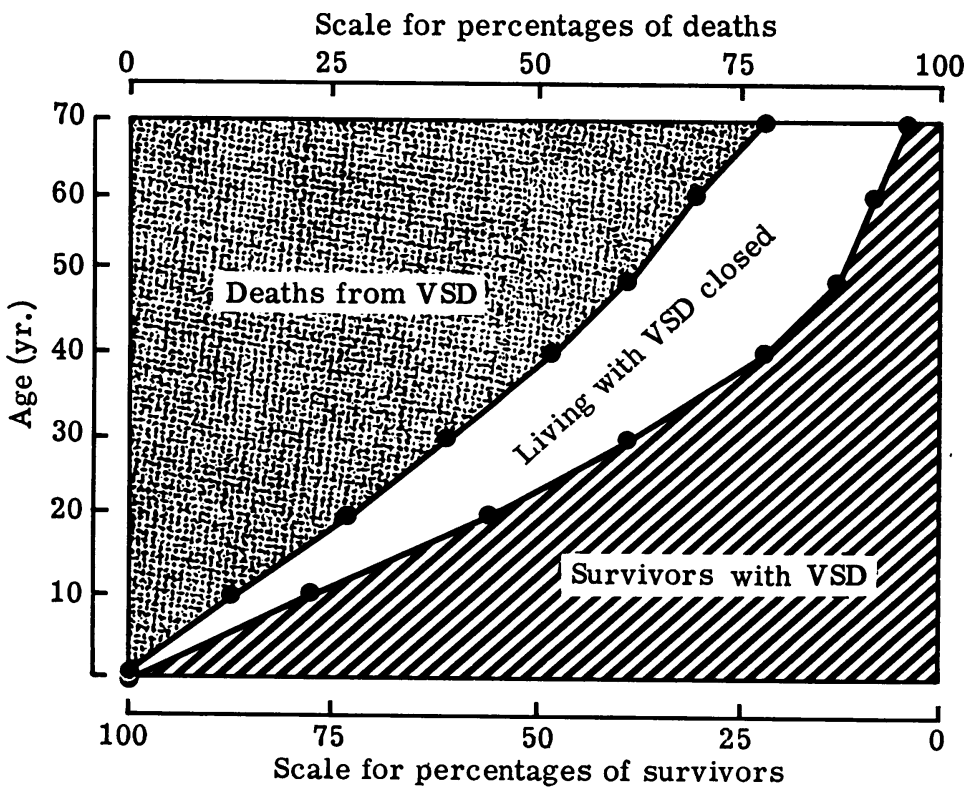


have found with most other cardiac malformations, though I was brought up to think that patients with ventricular septal defect were specially prone to have bacterial endocarditis.

Abbott (1936) in her famous Atlas found bacterial endocarditis the cause of death in 8.5 per cent of her 1000 cases. It was absent in atrial ostium secundum defect and only 4 per cent in Fallot's tetralogy; ro per cent in coarctation (excluding those with bicuspid aortic valves); 2 I per cent in persistent ductus, 25 per cent in ventricular septal defects, and 28 per cent in bicuspid aortic valves. She had too few cases of lone pulmonary stenosis or congenital aortic stenosis for comparison.

I am disappointed that my figures for its incidence in living patients and in reported necropsies (Campbell, 1970a, Table 5) are so discordant that I do not know in which conditions it is most common and can say only that its incidence is $0.9 \pm 0.4$ per cent per annum in all except atrial septal defect.

I have wondered if the modern child with his improved nutrition was less prone to bacterial endocarditis than in the past. My figures for persistent ductus and ventricular septal defect support this view, but those for aortic coarctation and pulmonary stenosis are against it.

\section{References}

Abbott, Maude (1936). Atlas of Congenital Heart Disease. American Heart Association, New York.

Agustsson, M. A., Gasul, B. M., Arcilla, R. A., Bicoff, J. P., and Mancadd, R. (1961). Spontaneous closure of ventricular septal defect in eight children demonstrated by serial cardiac catheterizations and by angiocardiography. Circulation, 24, 874 .

Bloomfield, D. K. (I964). The natural history of ventricular septal defect in patients surviving infancy. Circulation, 29, 914.

Blount, S. G., Mueller, H., and McCord, M. C. (1955). Ventricular septal defect: clinical and hemodynamic patterns. American fournal of Medicine, I8, 871.

-, and Woodwark, G. M. (1960). Considerations involved in the selection for surgery of patients with ventricular septal defects. American fournal of Cardiology, 5, 223.

Blumenthal, S. (1968). Natural history of ventricular septal defect with aortic valve prolapse. Proceedings of the Association of European Paediatric Cardiologists, 4, 25.

British Medical fournal (1967). Leading article: Spontaneous closure and treatment of ventricular septal defect. I, 379.

Brotmacher, L., and Campbell, M. (1958a). The natural history of ventricular septal defect. British Heart fournal, 20, 97.

$\longrightarrow$, and - (1958b). Ventricular septal defect with pulmonary stenosis. British Heart fournal, 20, 379.

Brown, J. W. (1939). Congenital Heart Disease. John Bale Medical Publications, London.

(1950). Congenital Heart Disease, 2nd ed. Staples Press, London.
Campbell, M. (1968a). Natural history of persistent ductus arteriosus. British Heart fournal, 30, 4 .

- (1968b). The natural history of congenital aortic stenosis. British Heart fournal, 30, 514 .

- (1968c). The incidence and later distribution of malformations of the heart. In Paediatric Cardiology, p. 71. Ed. by Hamish Watson. Lloyd-Luke (Medical Books), London.

(1969). Natural history of congenital pulmonary stenosis. In Aloisio Condorelli. LXX aetatis annum feliciter conficienti ex omnibus nationibus docti, viri scripta ad medicinam pertinentia honoris cause collecta d.d.d., p. 69. Rome.

- (1970a). Natural history of coarctation of the aorta. British Heart fournal, 32, 633.

(1970b). Natural history of atrial septal defect. British Heart fournal, 32, 820.

Carlgren, L.-E. (1959). The incidence of congenital heart disease in children born in Gothenburg, 1941-1950. British Heart fournal, 21, 40.

- (1969). The incidence of congenital heart disease in Gothenburg. Proceedings of the Association of European Paediatric Cardiologists, 5, 2.

Dammann, J. F., and Carpenter, Martha A. (1968). Ventricular septal defects. In Paediatric Cardiology, p. 468 . Ed. by H. Watson. Lloyd-Luke (Medical Books), London.

Dupré, E. (1891). Communication congenitales des deux coeurs par inocclusion de septum interventriculaire. Première observation de la lésion, reconnue pendant la vie et verifiée après la mort. Bulletins de la Société Anatomique de Paris, 66 (5me sér., 5), 404.

DuShane, J. N. (1968). The natural history and treatment of ventricular septal defect. Proceedings of the Association of European Paediatric Cardiologists, 4, Io.

Evans, J. R., Rowe, R. D., and Keith, J. D. (1960). Spontaneous closure of ventricular septal defects. Circulation, 22, 1044.

French, H. (1918). The possibility of a loud congenital heart murmur disappearing when a child grows up. Guy's Hospital Gazette, 32, 87.

Garcia, O., Mercado, H., Cañero, A. H., Castellanos, A., and Barrera, F. (1960). Some physiologic and hemodynamic observations in ventricular septal defect. American fournal of Cardiology, 5, 167.

Gasul, B. M., Dillon, R. F., Vrla, V., and Hait, G. (I957). Ventricular septal defects; their natural transformation into those with infundibular stenosis or into the cyanotic or noncyanotic type of tetralogy of Fallot. Fournal of the American Medical Association, 164, 847.

Gelfman, R., and Levine, S. A. (1942). The incidence of acute and subacute bacterial endocarditis in congenital heart disease. American fournal of the Medical Sciences, 204, 324.

Hoffman, J. I. E., and Rudolph, A. M. (1965). The natural history of ventricular septal defects in infancy. American fournal of Cardiology, 16, 634.

Hollman, A. (1967). Editorial. Ventricular septal defect. British Heart fournal, 29, 813.

Howitt, G., and Wade, E. G. (1962). Repeat catheterization in ventricular septal defect and pulmonary hypertension. British Heart fournal, 24, 649.

Hubbard, T. F., Angle, W. D., and Koszewski, B. J. (1957). Ventricular septal defect: a correlative clinical and physiologic study of fifty cases. American Heart fournal, 54, 210.

Joly, F., Carlotti, J., and Sicot, J. R. (195I). Les communications intraventriculaires: étude clinique and physiologique. Archives des Maladies du Coeur et des Vaisseaux, 44, 602. 
Jones, A. M., and Howitt, G. (1965). Eisenmenger syndrome in pregnancy. British Medical fournal, $\mathbf{1}$, 1627.

Lynfield, J., Gasul, B. M., Arcilla, R., and Luan, L. L. (1961). The natural history of ventricular septal defects in infancy and childhood. American fournal of Medicine, 30, 357.

Mannheimer, E., Ikkos, D., and Jonsson, B. (1957). Prognosis of isolated ventricular septal defects. British Heart fournal, 19, 333.

Nadas, A. S., Scott, L. P., Hauck, A. J., and Rudolph A. M. (I96I). Spontaneous functional closing of ventricular septal defects. New England fournal of Medicine, 264, 309.

Registrar General (1957). English Life Table No. II from his Decennial Supplement, England and Wales I95I.

Ritter, D. G., Feldt, R. H., Weidman, W. H., and Du Shane, J. W. (1965). Natural history and profiles in ventricular septal defect. Circulation, 32, Suppl. 3, p. 42.

Roger, H. (1879). Recherches cliniques sur la communication congénitale des deux coeurs, par inocclusion du septum interventriculaire. Bulletin de l'Académie de Médecine, $2 m e$ série, 8, 1074 and 1189.

Rudolph, A. M. (I968). The foetal circulation, circulatory adjustments after birth and the influence of congenital heart lesions on pulmonary haemodynamics. In Paediatric Cardiology, p. 48. Ed. by H. Watson. Lloyd-Luke (Medical Books), London. (1970). The foetal circulation and changes in the circulation after birth. Proceedings of the Association of European Paediatric Cardiologists, 6, 2.

Sandøe, E. (1963). Congenital Isolated Ventricular Septal Defect: Haemodynamics, Clinical Features, and Prognosis after the Age of Two Years. Munksgaard, Copenhagen.
Schrire, V., Vogelpoel, L., Beck, W., Nellen, M., and Swanepoel, A. (1965). Ventricular septal defect: the clinical spectrum. British Heart fournal, $27,813$.

Sellors, T. Holmes (1967). The genesis of heart surgery. British Medical fournal, $\mathbf{1}, 385$.

Selzer, A. (1949). Defect of the ventricular septum: summary of 12 cases and review of the literature. Archives of Internal Medicine, 84, 798.

-, and Laqueur, G. L. (1951). The Eisenmenger complex and its relation to the uncomplicated defect of the ventricular septum. Archives of Internal Medicine, 87, 218.

Shah, P., Singh, W. S. A., Rose, V., and Keith, J. D. (1966). Incidence of bacterial endocarditis in ventricular septal defects. Circulation, 34, 127.

Simmons, R. L., Moller, J. H., and Edwards, J. E. (1966). Anatomic evidence for spontaneous closure of ventricular septal defect. Circulation, 34, 38.

Varghese, P. J., Allen, J. R., Rosenquist, G. C., and Rowe, R. D. (1970). Natural history of ventricular septal defect with right-sided aortic arch. British Heart fournal, 32, 537.

Wade, G., and Wright, J. P. (1963). Spontaneous closure of ventricular septal defects. Lancet, $1,737$.

Weber, F. Parkes (1918). Can the clinical manifestations of congenital heart disease disappear with general growth and development of the patient? British fournal of Children's Diseases, 15, 113.

Wood, P. (1950). Congenital heart disease: a review of its clinical aspects in the light of experience gained by means of modern techniques. British Medical fournal, 2, 639 and 693 .

(1958). The Eisenmenger syndrome or pulmonary hypertension with reversed central shunt. British Medical fournal, 2, 701 and 755.

, Magidson, O., and Wilson, P. A. O. (1954). Ventricular septal defect, with a note on acyanotic Fallot's tetralogy. British Heart fournal, 16, 387. 